ROCZNIKI HUMANISTYCZNE

Tom LXVII, zeszyt $10-2019$

DOI: http://dx.doi.org/10.18290/rh.2019.67.10-5

JAROSŁAW KRAJKA

\title{
ELECTRONIC APPEARANCES IN TEIL INSTRUCTION - EXPANDING INTERCULTURAL TEACHER TRAINING WITH TELECOLLABORATIVE ACTIVITIES
}

\section{INTRODUCTION}

With increased student mobility, exchange programs, migrations and openings in the job market, teachers of English are increasingly likely to face the challenge of delivering foreign language instruction to multilingual classes, either at home or abroad. The issue of teachers' language awareness of diversity of Englishes has entertained some research to date. ${ }^{1}$ The main outlook on the matter was from the point of view of correctness, standards and variety introduced by different contexts in which English is used, ${ }^{2}$ with the crucial question of which English to teach asked by, for instance,

Jarosław Krajka (PhD, Hab), Department of Applied Linguistics, associate professor at Maria Curie-Skłodowska University in Lublin, Poland; e-mail: jarek.krajka@poczta.umcs.lublin.pl

${ }^{1}$ Cf. R. CARTER, How aware should language aware teachers and learners be? in: Language Awareness in Language Education, ed. D. Nunan, R. Berry, V. Berry, Hongkong: Department of Curriculum Studies, The University of Hong Kong 1995, p. 1-15; D. CRYstal, The future of Englishes: Going local, in: From International to Local English - And Back Again, ed. R. Facchinetti, D. Crystal, B. Seidlhofer, Bern: Peter Lang 2010, p. 17-25; T.S.C. Farrell, S. Martin, To teach Standard English or World Englishes? A balanced approach to instruction, "English Teaching Forum" 47(2009), nr 2, p. 2-7; K. HAZEN, Teaching about dialects, "ERIC Digest" "ERIC Digest" (2001), http://files.eric.ed.gov/fulltext/ED456674.pdf (access: 10.11.2017); M. LEWANDOwsKI, The dimensions of learner attitudes to General British and General American: A survey-based study, "Poznań Studies in Contemporary Linguistics" 53(2017), nr 2, p. 227-250.

${ }^{2}$ C. Nelson, Intelligibility and world Englishes in the classroom, "World English" 14(1995), nr 2, p. 273-279. 
Dziubalska-Kołaczyk, ${ }^{3}$ Farrell and Martin ${ }^{4}$ or Rinvolucri. ${ }^{5}$ The role of teaching World Englishes to promote intercultural awareness and increased understanding has been stressed, for instance, by Matsuda ${ }^{6}$ or Modiano, ${ }^{7}$ to name just a few.

However, even though the English as an International Language contexts (EIL) are quite thoroughly described, ${ }^{8}$ the actual implementation of EIL issues into the teacher training curriculum has been relatively underexplored, with some light on the matter shed by Maley ${ }^{9}$ or Wysocka. ${ }^{10}$ One of our previous studies ${ }^{11}$ attempted to sketch the path for the development of a blended learning component aimed at increasing intercultural teaching awareness. It is in this context that the present study, designed to observe the implementation of telecollaboration in Teaching English as an International Language (TEIL) training, is placed.

The question arises, thus, how to organise teacher training in highly monocultural and monolingual contexts. Well-designed telecollaborative activities, skillfully interwoven with regular instruction, are bound to help student teachers become more sensitive to the sociocultural context of language teaching worldwide. The present paper will show how a selected telecollaborative format, 'electronic appearances', could be used to supplement TEIL instruction to accomplish those purposes and improve the quality of English language teacher training at the graduate level.

${ }^{3}$ K. Dziubalska-KoŁaczyK, Native or non-native? This is the question: Which English to teach in the globalizing world? in: Proceedings of PTLC 2005, Londyn 2005, https://www.ucl.ac.uk/ pals/study/cpd/cpd-courses/ptlc/proceedings_2005/ptlcp67 (dostęp: 30.08.2016).

${ }^{4}$ T.S.C. Farrell, S. Martin, To teach Standard English, p. 2-7.

${ }^{5}$ M. RinvoluCRI, What sort of standard does English as a Lingua Franca (ELF) need to reach?, "The Teacher" 12(2006), nr 44, p. 35-36.

${ }^{6}$ A. MATSUdA, 'International understanding' through teaching world Englishes, "World Englishes" 21(2002), nr 3, p. 436-440; A. MATsuda, The ownership of English in Japanese secondary schools, "World Englishes" 22(2003), nr 4, p. 483-496.

${ }^{7}$ M. Modiano, Ideology and the ELT practitioner, "International Journal of Applied Linguistics" 11(2001), nr 2, p. 159-173.

${ }^{8}$ S.L. McKAY, Teaching English as an International Language, Oxford: Oxford University Press 2002; B. SEIDLHOFER, Research perspectives on teaching English as a lingua franca, "Annual Review of Applied Linguistics" 24(2004), p. 209-239; B. Seidlhofer, English as a lingua franca, "ELT Journal", 59(2005), nr 4, p. 339-341.

${ }^{9}$ A. MALey, The reality of EIL and the myth of EFL, in: EIL, EFL, Global English: Teaching and Learning Issues vol. 96, red. C. Gagliardi, A. Maley, Bern: Peter Lang 2010, p. 25-44.

${ }^{10}$ M. WysockA, Teaching English as an International Language: problems and research questions, in: Psycholinguistic and Sociolinguistic Perspectives on Second Language Learning and Teaching, red. K. Droździał-Szelest, M. Pawlak, Berlin-Heidelberg: Springer 2013, p. 41-55.

${ }^{11}$ J. KRAJKA, Preparing language teachers for multinational classrooms-guidelines for foreign language methodology training, in: Coping with Diversity: Language and Culture Education, red. H. Komorowska, L. Aleksandrowicz-Pędich, Warszawa: Academica Wydawnictwo SWPS 2010, p. 242-262. 


\section{ELECTRONIC APPEARANCES AS INTERNET-BASED INTERPERSONAL EXCHANGE TASKS}

It is generally agreed that the Internet has great potential for information collection and analysis. Such first-generation Internet activity formats as WebQuests, virtual fieldtrips or online research modules can still be highly successful in the classroom, since they motivate students and create authentic learning contexts. However, it is also important to let students interact with the speakers from the target language community, engaging learners in real oral or written interaction on interesting topics. Hence great importance of interpersonal exchanges, or tasks that make use of communication tools provided by the Web (email, chat, social media, audio/video conferencing) and involve transfer of information with other users. There exists a plethora of research into the use of varied Computer-Mediated Communication tools for language acquisition and teacher training, ${ }^{12}$ the use of telecollaboration in language proficiency development ${ }^{13}$ as well as in making teachers ready for delivering instruction in multicultural classrooms in technology-rich contexts $^{14}$. The existing body of research seems to point at the need for seeking

${ }^{12}$ T. Anderson, The virtual conference: Extending professional education in cyberspace, "International Journal of Educational Telecommunications" 2(1996), nr 2/3, p. 121-135; T. ANDerson, H. Kanuka, On-line forums: New platforms for professional development and group collaboration, "Journal of Computer-Mediated Communication" 3(1997), nr 3, http://onlinelibrary. wiley.com/doi/10.1111/j.1083-6101.1997.tb00078.x/full (access: 10.11.2017); L.K.L. CoMPTON, From Chatting to Confidence: A Case Study of the Impact of Online Chatting on International Teaching Assistants' Willingness to Communicate, Confidence Level and Fluency in Oral Communication, Ames, IA: Iowa State University 2002; L.K.L. Compton, From chatting to oral fluency: Using chat to improve self-confidence and increase willingness to communicate, "Teaching English with Technology" 4(2004), nr 1, http://www.tewtjournal.org/?wpdmact=process\&did=MTQ0Lmhvd Gxpbms (access: 10.11.2017); K. JAGIEtowicz, Computer-Mediated Communication: A critical perspective, "Teaching English with Technology" 2(2002), nr 1, http://www.tewtjournal.org/? wpdmact=process \&did=NjUuaG90bGluaw (access: 10.11.2017); J. HARrIs, Curriculum-based telecollaboration. Using activity structures to design student projects, "Learning and Leading with Technology” 26(1998), nr 1, p. 6-15; M. KöTTER, Negotiation of meaning and codeswitching in online tandems, "Language Learning \& Technology" 7(2003), nr 2, p. 145-172, http://1lt.msu. edu/vol7num2/kotter (access: 10.11.2017).

${ }^{13}$ See, for instance, K. BeAtTy, D. NunAn, Computer-mediated collaborative learning, "System" 32(2004), nr 2, p. 165-183; J. EDGE, Computer-mediated cooperative development: Non-judgmental discourse in online environments, "Language Teaching Research" 10(2006), nr 2, p. 205-227; M. Green, L. Cifuentes, An exploration of online environments supporting follow-up to face-to-face professional development, "Journal of Technology and Teacher Education" 16(2008), nr 3, p. 283-306.

${ }^{14}$ H. AN, S. KIM, B. KIM, Teacher perspectives on online collaborative learning: Factors perceived as facilitating and impeding successful online group work, "Contemporary Issues in Technology and Teacher Education” 8(2008), nr 1, p. 65-83; N. Arnold, L. Ducate, Future 
quality pedagogical designs, rather than only implementing cutting-edge technologies, which could be used to organise and mediate the instructional process.

As a kind of interpersonal exchange tasks, 'Electronic Appearances' is an activity structure in which authors, scientists or other professionals appear online to answer student questions or participate in discussions relevant to their professional lives, usually restricted to very brief time frames. As Harris ${ }^{15}$ describes, $\mathrm{CMC}$ tools such as electronic mail, newsgroups and electronic bulletin boards in first-generation Internet or Facebook, Twitter, messengers or Skype in Web 2.0 or 3.0 can help 'host' special guests, locally, nationally, or internationally-known people students can communicate with for relatively short periods of time. Although electronic appearances are certainly possible with e-mail and asynchronous computer-conferencing tools, most are done with real-time chat, messenger or videoconferencing programs, giving the participants a telepresence experience and accommodating the short-term and intensive nature of this kind of activity.

Electronic Mentoring is similar in structure to Electronic Appearances, but occurring with subject area specialists for longer time periods. As Harris ${ }^{16}$ claims, Internet-connected subject matter specialists from universities, businesses, government, or other schools can serve as electronic mentors to students wanting to explore specific topics of study in an interactive format on an ongoing basis. Here Harris gives the example of a 'matching service' called the 'Electronic Emissary, ${ }^{17}$ which helped volunteer subject matter experts (SMEs) from all over the world and teachers and their classes find each other, structure a mentoring project, and share what they learn together by communicating with electronic mail. This happened when occasional and basically unstructured contacts with

foreign language teachers' social and cognitive collaboration in an online environment, "Language Learning \& Technology" 10(2006), nr 1, p. 42-66; R. Hampel, U. STICKLER, New skills for new classrooms: Training tutors to teach languages online, "Computer Assisted Language Learning" 18(2005), nr 4, p. 311-326; M. KLEBAN, Teacher education needs 'Multivoiced learning spaces': Reflections on the encounters between Polish and international students, in: Coping with Diversity: Language and Culture Education, red. H. Komorowska, L. Aleksandrowicz-Pędich, Warszawa: Academica Wydawnictwo SWPS 2010, p. 275-288; P. Topol, R. Muffoletto, S. Gilbert, Międzykulturowy projekt wspótpracy UAM-ASU w kształceniu nauczycieli, w: Procesy globalizacji a kształcenie nauczycieli. Spojrzenie międzykulturowe, red. S. Dylak, R. Pęczkowski, P. Denicolo, Rzeszów: Wydawnictwo Uniwersytetu Rzeszowskiego 2006, p. 325-334.

${ }^{15}$ J. HARRIS, Education telecomputing projects: Interpersonal exchanges, "The Computing Teacher" 22(1995), nr 6, http://lrs.ed.uiuc.edu/Mining/March95-TCT.HTML (access: 10.11.2017).

${ }^{16}$ Ibidem.

${ }^{17}$ J. HARRIS, The Electronic Emissary: Bringing together students, teachers and subject matter experts, "The Computing Teacher" 21(1994b), nr 6, http://lrs.ed.uiuc.edu/Mining/August-September94-TCT.html (access: 10.11.2017). 
SMEs became more extended, progressing into a "teleapprenticeship", ${ }^{18}$ in which Internet-connected specialists from universities, businesses, governments, or other schools served as electronic mentors to students who wanted to explore specific study topics in an interactive format. In contrast to Electronic Appearances, a student communicates with a subject matter expert, a teacher, or a tutor, who accepts to accompany and assist him/her for a longer period of time.

Finally, Impersonations are a type of electronic appearances distinguished by the presence of an individual who plays the role of a literary or historical character. As Harris explains, ${ }^{19}$ with this structure at least one participant in an online group (either a person working at some remote place or one of the students) communicates as a character. When students can become on-line characters, one can develop a rich and motivational activity that lets them explore many topics in a dynamic and interactive context.

Even though these interpersonal exchange activity formats were proposed in the first-generation Internet, and were, at that time, accomplished via such CMC tools as listserves, bulletin boards or text-based chat, the very formats are relevant also at the present moment, especially for authenticating teacher training. The change of a medium to more modern means of expression does not change the very structure of the task, which is demonstrated in the study below.

\section{METHODOLOGY}

\subsection{THE AIM OF THE STUDY}

The aim of the current study was to investigate the feasibility of using selected telecollaborative activities in a face-to-face course of Teaching English as an International Language. The TEIL course constitutes a part of the graduate TEFL module at University of Social Sciences and Humanities in Warsaw, Poland, and demands bringing the international focus to sensitise student teachers of English to linguistic and cultural diversity of ELT classrooms all over the world, as well as building their awareness of the importance of second culture acquisition, multilingualism and intercultural awareness raising, alongside second language acquisition and foreign language teaching methodology.

${ }^{18}$ J.A. Levin, A. Rogers, M.L. Waugh, K. Smith, Observations on educational electronic networks: The importance of appropriate activities for learning, "The Computing Teacher" 16(1989), p. 17-21.

${ }^{19}$ J. HARris, Education telecomputing projects. 
It was the researcher's intention, thus, to see the effect of small-scale telecollaboration-based intervention on the instructional effectiveness of course completion on the one hand and student teachers' (STs henceforth) perceptions of their own intercultural teaching competence. At the same time, exposing the social aspect of telecollaboration ${ }^{20}$ was essential to increase student teachers' awareness of how to teach English to learners from differing backgrounds.

\subsection{The STUDY CONTEXT}

The study was conducted with a group of approximately 25 graduate students of English in two iterations ( 25 in the first, 23 in the second), who were in their first year of the graduate TEFL programme at University of Social Sciences and Humanities. The participants attended a 20 -hour TEIL class in the extramural mode, which was especially conducive to bringing external teachers' input through telecollaboration.

The specific contents of the course included the following topics and assignments:

- becoming aware of the distinctions between English as an International Language (EIL), Lingua Franca Core (LFC), Circles of English, New Englishes, Globish;

- finding out aspects of the sociocultural context of language acquisition and stages of second culture acquisition;

- understanding strengths and weaknesses of native vs. non-native teachers of English;

- investigating status of English all over the world, comparing teaching in one's home country with others;

- evaluating and adapting materials to gain a culturally-sensitive dimension;

- learning to exploit linguistic potential of New Englishes in the classroom.

The Teaching English as an International Language module was embedded in the overall post-graduate teaching specialization in the way represented in Table 1. For the purposes of training multi-cultural and culturally-sensitive English language teachers, the TEIL subject was actually the core of the module, with Lesson Observation and Evaluation, Materials Evaluation and Language Testing feeding specific skills to it, while Autonomy in Language Learning and Information and Communication Technology giving opportunities for

${ }^{20}$ J.A. Belz, Social dimensions of telecollaborative foreign language study, "Language Learning \& Technology" 6(2002), nr 1, p. 60-81. 
practicing diversifying modes of language instruction for use in different parts of the world.

Table 1. Post-graduate teaching specialization structure at University of Social Sciences and Humanities

\begin{tabular}{|l|l|l|}
\hline & \multicolumn{1}{|c|}{ Winter term } & \multicolumn{1}{|c|}{ Summer term } \\
\hline Year I & $\begin{array}{l}\text { "Psychology: Selected Issues" } \\
\text { "Pedagogical Theory: Selected Issues" } \\
\text {,Teaching Children and Adolescents" } \\
\text {,Teaching Adult Learners" }\end{array}$ & $\begin{array}{l}\text { "Lesson Observation and Evaluation" } \\
\text {,Language Testing” } \\
\text { ELT Materials Evaluation" }\end{array}$ \\
\hline Year II & $\begin{array}{l}\text { "New Trends in Language Education" } \\
\text { "Teaching English as an International } \\
\text { "Teaching English for Specific Purposes" }\end{array}$ & $\begin{array}{l}\text { "Success and Failure in Language Teaching" } \\
\text { "Autonomy in Language Learning } \\
\text { and Teaching" } \\
\text { "Information and Communication } \\
\text { Technology" }\end{array}$ \\
\hline
\end{tabular}

In particular, the syllabus of the experimental course included increasing student teachers' knowledge of the current state of English, the skills of researching nature of English language teaching in selected countries, constructing tests and lesson plans to fit diverse cultures of learning as well as adapting those created with other cultural/national contexts in mind. The schedule of the experimental course is given in Table 2 below.

Table 2. Teaching English as an International Language course syllabus

\begin{tabular}{|l|}
\hline 1. Sociocultural context of FLA \\
\hline 2. English as a global language \\
\hline 3. Changing English, World Englishes, regional varieties \\
\hline 4. Diverse contexts for ELT - ESL and World Englishes. Status of English in different countries \\
\hline 5. EIL language teacher: skills, competences, training, materials \\
\hline 6. ELF and culture. Teaching foreign languages in an intercultural world \\
\hline 7. Incorporating World Englishes and culture in curriculum design and lesson planning \\
\hline 8. Materials and aids in ELF. Culture and language in EFL course books \\
\hline 9. Student presentations - reading/listening comprehension tasks based on non-British varieties \\
\hline
\end{tabular}

\subsection{Design AND PROCEDURE}

This small-scale study was conducted over the period of two years, in two iterations. It followed the fashion of action research, with its essential stages of planning, acting, reflecting, evaluating, repeated twice with the use of 
telecollaborative activities. Qualitative data were collected via analysis of learning diaries, semi-structured classroom observation, assessment of authored lesson plans and informal group interviews. The assessment of student lesson plans was in line with the criteria established in one of the previous courses of the TEFL module, namely "Materials Evaluation and Adaptation," and comprised the following aspects: Relevance to task, Lesson feasibility, Didactic creativity and Grammatical accuracy.

The telecollaborative design used was that of "virtual appearances. ${ }^{21}$ This interpersonal exchange activity format, popular in the Web 1.0 phase alongside 'keypal exchanges' or 'ask-an-expert' tasks, presumes virtual participation of an expert in the didactic process in a traditional F2F class via synchronic and asynchronic tools. In the case of the present study, the experts were Polish students-participants of Comenius/AIESEC programs in Colombia, France, Norway, Turkey, Martinique. Allowing STs to experience telecollaboration as learners aimed at increasing their confidence as teachers to maximise the chance of telecollaborative learning in the future with instructors acting as 'guides on the side.'22

The telecollaborative supplement followed the task sequence as indicated below:

- Pre-stage: researching and assessing the status of English and the role of a language teacher in selected countries.

- While-stage: reading problems, proposing solutions, sending them to teachers-remote experts.

- Post-stage: discussing responses, reflecting on lesson plans.

The intervention was blended with regular face-to-face instruction, with experts contributing classroom problems, diary entries, lesson plans. The input was provided in the asynchronous mode, via email and Moodle-based discussion forum. For instance, the countries which the teaching assistants were based in, as well as other countries which their students might have originated from, were selected for individual research and in-class presentations on the status of English and the organization of language learning in that country as compared to a different one. Moreover, actual cases of classroom problems, contributed

${ }^{21}$ J. HARris, People-to-people projects on the Internet, "The Computing Teacher" 21(1994a), nr 5, http://lrs.ed.uiuc.edu/Mining/February94-TCT.html (access: 10.11.2017); J. Harris, The Electronic Emissary; J. HARRIs, Education telecomputing projects; J. HARRIS, Teachers as telecollaborative project designers: A curriculum-based approach, "Contemporary Issues in Technology and Teacher Education" 1(2001), nr 3, http://www.citejournal.org/vol1/iss3/seminal/article1.htm (access: 10.11.2017); M. VInAgre, Social interaction in telecollaborative language learning, paper presented during UNTELE 2007 conference Compiegne, March 2007.

${ }^{22}$ O'Dowd R., Eberbach K., Guides on the side? Tasks and challenges for teachers in telecollaborative projects, "ReCALL" 16(2004), nr 1, p. 5-19. 
by teaching assistants, were used at the beginning of each face-to-face class for group brainstorming on possible solutions. The ideas were collected and sent to the assistant for possible implementation. The cases were later generalized and referred to some theoretical frameworks. ${ }^{23}$ This is how, gradually, students' awareness of different cultures and conditions for language teaching and learning was supposed to grow gradually.

Polish student teachers (STs) participated in a graduate TEIL course in a regular classroom, dealing with Teaching English as an International Language topics as outlined in Table 2 above, while the virtual component was supposed to give STs a wider perspective on teaching in international contexts. The Moodle coursespace contained texts, videos, teaching problems, diary entries, while Comenius Assistants made virtual appearances in the form of posting teaching diary entries, seeking advice to teaching problems or pinpointing cross-cultural issues. Some of the materials for analysis included actual coursebook units, lesson of fellow teachers from remote countries, sample tests or exam requirements. Quite interestingly, remote presence of Comenius assistants sometimes proved quite dramatic, as in the example of a teacher struggling with the challenge of Colombian educational system given in Table $3 \mathrm{~s}$.

Table 3. Authentic input sent by AIESEC trainee teacher from Colombia

Szanowny Panie Profesorze,

po kilku tygodniach pobytu w Kolumbii i niespełna dwóch tygodniach pracy w tutejszej szkole chciałabym się z Panem podzielić moimi dotychczasowymi doświadczeniami, ale też (albo szczególnie) poprosić o porady. Każde zajęcia wyglądają tak samo - dzieci czytają fragment historii, a ja zadaję im pytania, żeby ich choć trochę przybliżyć do tego, o co w danym paragrafie chodzi. Pomijam trudne słowa, a na tablicy zapisuję te najłatwiejsze, bo one też sprawiają trudność. W książce jest wiele przykładów ćwiczeń w grupach lub parach, ale z tymi dziećmi to nie wychodzi. Klasy są bardzo liczne - aż 30 osób, a poziom bardzo zróżnicowany. Poza tym zadania te są trudne i wymagają zrozumienia treści, a tylko nieliczni wiedzą, o czym czytają. Na dodatek w klasach nie ma dyscypliny. Nie działają żadne prośby, groźby, kary i nagrody. Niektórzy śpią na lekcjach, a inni patrzą przez okno i nawet nie notują. $\mathrm{O}$ ciągłych rozmowach w j. hiszpańskim i nieustającym hałasie nie wspominając...

Wiedziałam, że nie będzie łatwo, ale to, co się tutaj dzieje to jakiś koszmar...

Rozmawiałam o tym z przełożonym, który owszem, pouczył dzieci, ale efekty były widoczne tylko przez kilka lekcji. Co do zmiany nauczanych treści to nawet nie ma co o tym marzyć.

Panie Profesorze, co mogę w takiej sytuacji zrobić?

To dopiero drugi tydzień w szkole, a ja jestem wypalona i zestresowana, jak nigdy przedtem... Bardzo liczę na Pańską odpowiedź.

${ }^{23}$ G. Hofstede, Culture's Consequences: Comparing Values, Behaviors, Institutions, and Organizations Across Nations, Thousand Oaks, CA: Sage 2001; G. Hofstede, G.J. Hofstede, M. Minkov, Cultures and Organizations: Software of the Mind, New York, NY: McGraw-Hill Publishing 2010. 


\section{RESULTS AND DISCUSSION}

On the one hand, it was interesting to see how student teachers' ability to design, adapt and implement TEFL instruction sensitive to linguistic and cultural background changed after the telecollaboration-enhanced TEIL course. In this respect, the following findings were drawn from the qualitative data yielded by the study, supported by quotes taken out from trainee diaries:

- STs reported high personal language proficiency, most notably within receptive skills.

- STs generally did not feel a need to constantly develop their language skills, especially with global English input.

- Prior to the intervention, few respondents were aware of what L2 standard they were pursuing, also few displayed even minor awareness of the differences between standards (e.g., British English vs. American English), as well as between 'Standard English' and 'New Englishes', as demonstrated in the quote below:

I didn't think much about standards in English, of course, I could hear American English pronunciation is different, but I didn't have enough knowledge about other areas of language use. Now I can show major features of American English, as well as other major Englishes.

- STs generally had numerous ideas on the way that English should be taught to multilingual/multicultural classes and show the skills of adapting instruction to fit diverse contexts, thus displaying their creativity, however, the ideas were not coupled with their perception of possession of skills needed to do that.

- STs increased their awareness of standards, issues of global nature of English, circles of English, diversity of language, though they saw that their understanding of standards in language teaching has to accommodate these.

I didn't know there is more than one English, I thought English is what we learn at university. I need to make some meaning of that for myself, it's slightly fuzzier now.

It's helpful to know as a non-native speaker I am not in the worse position - I think it's unfair that some language schools appreciate native speakers only by virtue of their origin, not taking education, skills or diplomas into account.

- In-class presentations on contexts of ELT all over the world and authored lesson plans based on New Englishes input were of generally high quality, indicating significant effort put into the process. 
- It took me a great amount of time to prepare the lesson plans - not so much finding materials from World Englishes, this was easy, but laying out the whole plan, coming up with aims and objectives. I'm glad you don't have to make such detailed plans when teaching at school.

It was especially the combination of more theoretical issues introduced in class, forming the basis for practical investigations, and pedagogical activities based on global English language teaching input contributed to the class by telecollaborative experts that made the course challenging and comprehensive at the same time.

In terms of more specific aspects of language teaching, the analysis of learning diaries of participants showed a significant amount of reflection over the process of language assessment, the use of L1 vs. L2 in the classroom and translation as a learning activity. Especially the result of remote collaboration with a student teacher working in Turkey led to widening student teachers' array of testing techniques, as indicated in the quotes below:

The amount of L1 used by teachers in the lesson probably depends on the level and age of the ss, and complexity of the subject matter. Still, I guess, too much of L1 is used in an ordinary language lesson. Teachers are afraid that Ss won't be able to understand everything properly and they overuse L1 for giving instruction as well as during the presentation stage. Some Ss impose their using L1 on teachers by constant asking: Can I speak Polish, please thus trying to avoid any effort on their part to use L2.

In my opinion vocabulary can be tested by translation, however it shouldn't be the only way it's tested. Having an exercise that depends on that is perfectly okay, but a whole test, or even all tests, that rely on this method entirely, in my opinion doesn't work. Language should be acquired as a whole, and not only through independent words or sentences without context. As to age and level, I believe this might work best with older students, not with kids, that are on intermediate level or above.

Quite interesting findings were observed in terms of learners' perception of L1 vs. L2 use. Being raised in the "deep-end" Communicative Approach, in which first language use is scarce or discouraged, Polish student teachers were puzzled by the Turkish language teaching reality as indicated below:

When the students have difficulty in understanding, we generally use L1. In Turkey, the students are content with this situation. They want to hear in Turkish in 
order to understand better. In education system of Turkey, when we learn and teach English, we lack speaking and listening skills. It is generally based on grammar and theoretical knowledge. And unfortunately, most of the teachers are happy with this.

The second area of data collection was the perception of the telecollaborative design in the course. It was important to find out how student teachers evaluated the way that the traditional teacher training classroom could be enriched with electronic appearances. Here, the participants generally expressed their appreciation of telecollaborative sequences for authenticity, interest, asynchronous communication, real-life touch. The competence gap that was naturally created between practising teachers in remote countries and student teachers in Poland proved to be not that wide - skill-wise, both groups were on a roughly similar level. However, the so-called 'experts' were gaining intercultural teaching experience every day, thus, it can be claimed that it was context gap that was successfully exploited to foster the acquisition of global teaching skills. The expansion of the teacher training context can be evidenced in further learning diary entries as below:

The fact that students come from vastly different countries and cultures makes for great conversation starters in class. As teachers, we can use culture as a springboard to introduce class topics like worldwide holidays or food vocabulary or otherwise stimulate the class with new perpectives. Students who do not speak Polish can not be judged on the same measure as students who fluently use this language. It is good that all students understand that beyond good results, their effort and the progress made are also appreciated. A very important element of the teacher's work is individualization.

I guess that it is more difficult to test vocab and grammar in multilingual/multicultural classes, however I would test it in a way English-English, where students need to provide an explanation of the particular word for instance. There is the only way to test it in this kind of class.

At the same time, certain shortcomings of the telecollaborative design were also pinpointed:

- Electronic appearances were criticised for being mainly one-way communication - experts did not have enough time to engage in regular communication, instead, they mainly contributed input at the beginning and did not interact much throughout the process. 
- While STs expected more interaction in ECs, they complained about overall course workload. Since extramural studies had to be reconciled with work and family duties, increasing online workload might have been counter-productive.

- In general, differing expectations of both collaboration parties put full success of the process into question, and especially the study schedules of local students made it difficult to engage in more meaningful interaction with remote experts. As such, for logistical reasons, the mini-experiment was slightly less successful than expected, still, the pedagogical benefit achieved made it worthwhile implementing and reiterating in future teacher training.

\section{CONCLUSION}

In the study presented herein, technology-enhanced activities are not the centre of the course, but they play a significant part overall. Language awareness, TEIL, intercultural teaching competence call for skilful use of CALL procedures to increase the global dimension of teacher training. However, rather than implementing fully-fledged class-to-class telecollaboration, an alternative 'one-to-many' format can also prove useful to contribute input for classroom work. This will be the case on condition that the involvement of both parties of the telecollaborative exchange is made proportionately equal, that both teaching assistants-remote experts and teacher trainees see the added value of participation, that there are provisions for assessment of both face-to-face and telecollaborative component, finally, that the logistical and organisational issues are successfully resolved at the beginning as well as monitored and managed throughout the exchange. If all this happens, the purposeful competence gap (experts vs. trainees) will help to increase authenticity of TEIL instruction while blended learning opens up a natural context for culture-rich acquisition of teaching skills.

\section{REFERENCES}

An H., KIm S., Kim B., Teacher perspectives on online collaborative learning: Factors perceived as facilitating and impeding successful online group work, "Contemporary Issues in Technology and Teacher Education" 8(2008), nr 1, p. 65-83.

Anderson T., The virtual conference: Extending professional education in cyberspace, "International Journal of Educational Telecommunications" 2(1996), nr 2/3, p. 121-135. 
Anderson T., Kanuka H., On-line forums: New platforms for professional development and group collaboration, "Journal of Computer-Mediated Communication" 3(1997), nr 3, http:// onlinelibrary.wiley.com/doi/10.1111/j.1083-6101.1997.tb00078.x/full (access: 10.11.2017).

Arnold N., Ducate L., Future foreign language teachers' social and cognitive collaboration in an online environment, "Language Learning \& Technology" 10(2006), nr 1, p. 42-66.

Beatty K., Nunan D., Computer-mediated collaborative learning, "System" 32(2004), nr 2, p. $165-183$.

Belz J.A., Social dimensions of telecollaborative foreign language study, "Language Learning \& Technology" 6(2002), nr 1, p. 60-81.

CARTER R., How aware should language aware teachers and learners be? in: Language Awareness in Language Education, ed. D. Nunan, R. Berry, V. Berry, Hongkong: Department of Curriculum Studies, The University of Hong Kong 1995, p. 1-15.

Compton L.K.L., From Chatting to Confidence: A Case Study of the Impact of Online Chatting on International Teaching Assistants' Willingness to Communicate, Confidence Level and Fluency in Oral Communication, Ames, IA: Iowa State University 2002.

Compton L.K.L., From chatting to oral fluency: Using chat to improve self-confidence and increase willingness to communicate, "Teaching English with Technology" 4(2004), nr 1, http:// www.tewtjournal.org/?wpdmact=process\&did=MTQ0LmhvdGxpbms (access: 10.11.2017).

Crystal D., The future of Englishes: Going local, in: From International to Local English - And Back Again, ed. R. Facchinetti, D. Crystal, B. Seidlhofer, Bern: Peter Lang 2010, p. 17-25.

Dziubalska-KoŁaczy K., Native or non-native? This is the question: Which English to teach in the globalizing world? in: Proceedings of PTLC 2005, Londyn 2005, https://www.ucl.ac.uk/ pals/study/cpd/cpd-courses/ptlc/proceedings_2005/ptlcp67 (dostęp: 30.08.2016).

Edge J. Computer-mediated cooperative development: Non-judgmental discourse in online environments, "Language Teaching Research" 10(2006), nr 2, p. 205-227.

Farrell T.S.C., Martin S., To teach Standard English or World Englishes? A balanced approach to instruction, "English Teaching Forum" 47(2009), nr 2, p. 2-7.

Green M., Cifuentes L., An exploration of online environments supporting follow-up to faceto-face professional development, "Journal of Technology and Teacher Education" 16(2008), nr 3, p. 283-306.

Hampel R., Stickler U. New skills for new classrooms: Training tutors to teach languages online, "Computer Assisted Language Learning" 18(2005), nr 4, p. 311-326.

Harris J., People-to-people projects on the Internet, "The Computing Teacher" 21(1994a), nr 5, http://lrs.ed.uiuc.edu/Mining/February94-TCT.html (access: 10.11.2017).

HARRIS J., The Electronic Emissary: Bringing together students, teachers and subject matter experts, “The Computing Teacher" 21(1994b), nr 6, http://lrs.ed.uiuc.edu/Mining/August-September94-TCT.html (access: 10.11.2017).

HARRIS J., Education telecomputing projects: Interpersonal exchanges, "The Computing Teacher" 22(1995), nr 6, http://lrs.ed.uiuc.edu/Mining/March95-TCT.HTML (access: 10.11.2017).

HARris J. Curriculum-based telecollaboration. Using activity structures to design student projects, "Learning and Leading with Technology" 26(1998), nr 1, p. 6-15.

HARris J., Teachers as telecollaborative project designers: A curriculum-based approach, "Contemporary Issues in Technology and Teacher Education" 1(2001), nr 3, http://www.citejournal. org/voll/iss3/seminal/articlel.htm (access: 10.11.2017). 
Hazen K., Teaching about dialects, “ERIC Digest” (2001), http://files.eric.ed.gov/fulltext/ ED456674.pdf (access: 10.11.2017).

Hofstede G., Culture's Consequences: Comparing Values, Behaviors, Institutions, and Organizations Across Nations, Thousand Oaks, CA: Sage 2001.

Hofstede G., Hofstede G.J., Minkov M., Cultures and Organizations: Software of the Mind, New York, NY: McGraw-Hill Publishing 2010.

Hudson R., The language teacher and descriptive versus prescriptive norms: The educational context, lecture given during workshops on prescriptivism in foreign language teaching, Paryż 2000, http://lagb-education.org/wp-content/uploads/2016/01/SEhudson.pdf (access: 10.11.2017).

JaGieŁowicz K., Computer-Mediated Communication: A critical perspective, "Teaching English with Technology" 2(2002), nr 1, http://www.tewtjournal.org/?wpdmact=process\&did=NjUuaG90bGluaw (access: 10.11.2017).

KLeBan M., Teacher education needs 'Multivoiced learning spaces': Reflections on the encounters between Polish and international students, in: Coping with Diversity: Language and Culture Education, red. H. Komorowska, L. Aleksandrowicz-Pędich, Warszawa: Academica Wydawnictwo SWPS 2010, p. 275-288.

KötTER M., Negotiation of meaning and codeswitching in online tandems, "Language Learning \& Technology" 7(2003), nr 2, p. 145-172, http://1tt.msu.edu/vol7num2/kotter (access: 10.11.2017).

KRAJKa J., Preparing language teachers for multinational classrooms - guidelines for foreign language methodology training, in: Coping with Diversity: Language and Culture Education, red. H. Komorowska, L. Aleksandrowicz-Pędich, Warszawa: Academica Wydawnictwo SWPS 2010, p. 242-262.

LEE S., Native and non-native listeners' sensitivity to English onset restrictions and universal onset markedness, "Poznań Studies in Contemporary Linguistics" 52(2016), nr 4, p. 687-718.

Levin J.A., Rogers A., Waugh M.L., Smith K., Observations on educational electronic networks: The importance of appropriate activities for learning, "The Computing Teacher" 16(1989), p. 17-21.

Lewandowski M., The dimensions of learner attitudes to General British and General American: A survey-based study, "Poznań Studies in Contemporary Linguistics" 53(2017), nr 2, p. $227-250$.

MALEy A., The reality of EIL and the myth of EFL, in: EIL, EFL, Global English: Teaching and Learning Issues vol. 96, red. C. Gagliardi, A. Maley, Bern: Peter Lang 2010, p. 25-44.

Matsuda A., 'International understanding' through teaching world Englishes, "World Englishes" 21(2002), nr 3, p. 436-440.

Matsuda A., The ownership of English in Japanese secondary schools, "World Englishes" 22(2003), nr 4, p. 483-496.

McKay S.L., Teaching English as an International Language, Oxford: Oxford University Press 2002.

ModiAno M., Ideology and the ELT practitioner, "International Journal of Applied Linguistics" 11(2001), nr 2, p. 159-173.

Nelson C., Intelligibility and world Englishes in the classroom, "World Englishes" 14(1995), nr 2, p. 273-279.

O'Dowd R., Eberbach K., Guides on the side? Tasks and challenges for teachers in telecollaborative projects, "ReCALL" 16(2004), nr 1, p. 5-19. 
RinVoluCRi M., What sort of standard does English as a Lingua Franca (ELF) need to reach?, "The Teacher" 12(2006), nr 44, p. 35-36.

SEIDLhofer B., Research perspectives on teaching English as a lingua franca, "Annual Review of Applied Linguistics" 24(2004), p. 209-239.

Seidlhofer B., English as a lingua franca, "ELT Journal" 59(2005), nr 4, p. 339-341.

Topol P., Muffoletto R., Gilbert S., Międzykulturowy projekt wspótpracy UAM-ASU w kształceniu nauczycieli, in: Procesy globalizacji a kształcenie nauczycieli. Spojrzenie międzykulturowe, red. S. Dylak, R. Pęczkowski, P. Denicolo, Rzeszów: Wydawnictwo Uniwersytetu Rzeszowskiego 2006, p. 325-334.

VINAGRE M., Social interaction in telecollaborative language learning, paper presented during UNTELE 2007 conference Compiegne, March 2007.

WysocKa M., Teaching English as an International Language: problems and research questions, in: Psycholinguistic and Sociolinguistic Perspectives on Second Language Learning and Teaching, red. K. Droździał-Szelest, M. Pawlak, Berlin-Heidelberg: Springer 2013, p. 41-55.

\section{ELEKTRONICZNA OBECNOŚĆ W NAUCZANIU JĘZYKA ANGIELSKIEGO JAKO MIĘDZYNARODOWEGO - WSPOMAGANIE PROCESU KSZTAŁCENIA NAUCZYCIELI ZADANIAMI TELE-WSPÓŁPRACY}

\section{Streszczenie}

Wobec wielu badań empirycznych i publikacji praktycznych poświęconych definiowaniu i rozwijaniu kompetencji interkulturowej i interkulturowej kompetencji komunikacyjnej uczniów, dużo mniej badań dotyczyło kompetencji, umiejętności i postaw nauczyciela niezbędnych dla prowadzenia procesu glottodydaktycznego z uwzględnieniem różnic kulturowych uczniów w klasach wielojęzycznych i wielokulturowych (por. Farrell i Martin 2009; Krajka 2010; Wysocka 2013). Uwzględnienie globalnego wymiaru nauczania języka obcego stało się koniecznością we współczesnej edukacji językowej, a umiejętne wykorzystanie elementu współpracy zapośredniczonej przez Internet (telecollaboration) pozwala na nadanie bardziej autentycznego wymiaru kształceniu językowemu.

Celem artykułu jest ukazanie możliwości zastosowania wybranego formatu zadań realizowanych we współpracy zapośredniczonej przez Internet, 'elektronicznej obecności' (electronic appearances) w procesie rozwijania umiejętności nauczania języka angielskiego jako języka międzynarodowego (Teaching English as an International Language - TEIL) na neofilologicznych studiach magisterskich.

Słowa kluczowe: TEIL; współpraca zapośredniczona przez Internet; electronic appearances; kształcenie nauczycieli.

\section{ELECTRONIC APPEARANCES IN TEIL INSTRUCTION - EXPANDING INTERCULTURAL TEACHER TRAINING WITH TELECOLLABORATIVE ACTIVITIES}

$$
\text { S u m m a r y }
$$

While a great amount of research has been devoted to defining and developing intercultural competence and intercultural communicative competence of learners, fewer studies have focused 
upon the competences needed to choose materials and methods, plan, organise and implement language teaching in a culturally-sensitive way (e.g., Farrell and Martin 2009; Krajka 2010; Wysocka 2013). Focusing on global dimensions of language teaching has become a must in contemporary Teaching English as a Foreign Language (TEFL) education, and skilful integration of telecollaborative projects can authenticate culture-sensitive teacher education. The paper shows the use of a selected telecollaborative format, 'electronic appearances', to supplement Teaching English as an International Language (TEIL) class at a post-graduate TEFL programme.

Key words: TEIL; telecollaboration; electronic appearances; teacher training. 